\title{
Storage protein profiles in Spanish and runner market type peanuts and potential markers XQ Liang $1,2, \mathrm{M} \mathrm{Luo}^{1,3}$, CC Holbrook${ }^{4}$ and BZ Guo*1
}

Address: ${ }^{1}$ USDA-ARS, Crop Protection and Management Research Unit, Tifton, GA, USA, ${ }^{2}$ Guangdong Academy of Agricultural Sciences, Institute of Crop Sciences, Guangzhou, China, ${ }^{3}$ University of Georgia, Department of Crop and Soil Sciences, Tifton, GA, USA and ${ }^{4}$ USDA-ARS, Crop Genetics and Breeding Research Unit, Tifton, GA, USA

Email: XQ Liang - liang804@yahoo.com; M Luo - mluo@tifton.uga.edu; CC Holbrook - holbrook@tifton.usda.gov; BZ Guo* - bguo@tifton.usda.gov

* Corresponding author

Published: 12 October 2006

BMC Plant Biology 2006, 6:24 doi:10.1 |86//47|-2229-6-24
Received: 15 June 2006

Accepted: 12 October 2006

This article is available from: http://www.biomedcentral.com/I47I-2229/6/24

(c) 2006 Liang et al; licensee BioMed Central Ltd.

This is an Open Access article distributed under the terms of the Creative Commons Attribution License (http://creativecommons.org/licenses/by/2.0), which permits unrestricted use, distribution, and reproduction in any medium, provided the original work is properly cited.

\begin{abstract}
Background: Proteomic analysis has proven to be the most powerful method for describing plant species and lines, and for identification of proteins in complex mixtures. The strength of this method resides in high resolving power of two-dimensional electrophoresis (2-DE), coupled with highly sensitive mass spectrometry (MS), and sequence homology search. By using this method, we might find polymorphic markers to differentiate peanut subspecies.
\end{abstract}

Results: Total proteins extracted from seeds of 12 different genotypes of cultivated peanut (Arachis hypogaea L.), comprised of runner market (A. hypogaea ssp. hypogaea) and Spanish-bunch market type (A. hypogaea ssp. fastigiata), were separated by electrophoresis on both one- and twodimensional SDS-PAGE gels. The protein profiles were similar on one-dimensional gels for all tested peanut genotypes. However, peanut genotype AI 3 lacked one major band with a molecular weight of about $35 \mathrm{kDa}$. There was one minor band with a molecular weight of $27 \mathrm{kDa}$ that was present in all runner peanut genotypes and the Spanish-derivatives (GT-YY7, GT-YY20, and GTYY79). The Spanish-derivatives have a runner-type peanut in their pedigrees. The $35 \mathrm{kDa}$ protein in Al3 and the $27 \mathrm{kDa}$ protein in runner-type peanut genotypes were confirmed on the 2-D SDSPAGE gels. Among more than 150 main protein spots on the 2-D gels, four protein spots that were individually marked as spots $\mathrm{I}-4$ showed polymorphic patterns between runner-type and Spanishbunch peanuts. Spot I (ca. $22.5 \mathrm{kDa}$, pl 3.9) and spot 2 (ca. $23.5 \mathrm{kDa}$, pl 5.7) were observed in all Spanish-bunch genotypes, but were not found in runner types. In contrast, spot 3 (ca. $23 \mathrm{kDa}$, pl 6.6) and spot 4 (ca. $22 \mathrm{kDa}, \mathrm{pl}$ 6.8) were present in all runner peanut genotypes but not in Spanishbunch genotypes. These four protein spots were sequenced. Based on the internal and $\mathrm{N}$-terminal amino acid sequences, these proteins are isoforms (iso-Ara h3) of each other, are iso-allergens and may be modified by post-translational cleavage.

Conclusion: These results suggest that there may be an association between these polymorphic storage protein isoforms and peanut subspecies fastigiata (Spanish type) and hypogaea (runner type). The polymorphic protein peptides distinguished by 2-D PAGE could be used as markers for identification of runner and Spanish peanuts. 


\section{Background}

There is considerable variation in Arachis hypogaea L. subspecies hypogaea and fastigiata Waldron, which are further classified into four market types including runner, Virginia, Spanish, and Valencia [1]. Most cultivated peanuts belong to Spanish and runner types. They exhibit genetically-determined variation for a number of botanical and agronomical traits including branching and flowering habits, seed dormancy, and maturation time. However, there are few categorical criteria for distinguishing subspecies because of the limited detectable molecular polymorphism. Recently, several molecular approaches have been employed to assess genetic diversity and taxonomic relationships. Among them are isozymes [2], restriction fragment length polymorphisms (RFLP), random amplified polymorphisms (RAPD), amplified fragment length polymorphisms (AFLP), and simple sequence repeats (SSR) [3-6]. However, very little genetic polymorphism between the two subspecies was detected. Singh et al. $[7,8]$ and Bianchi-Hall et al. [9] found very limited or no variation among cultivated peanut based on seed protein profiles.

To date, proteomic analysis has proven to be the most powerful method for describing plant species and lines $[10]$, and identification for proteins (especially protein markers) in complex mixtures. The strength of this method resides in high resolving power of two-dimensional PAGE (2D-PAGE), coupled with polypeptide sequencing by highly sensitive mass spectrometry (MS) such as electrospray ionization tandem mass spectrometry (ESI-MS/MS), and sequence homology search in databases [11].

The aim of the research described in this paper was to investigate the ability of proteomic analysis to assess diversity of seed storage proteins in peanut for subspecies or cultivar identification. Subspecies or cultivar-specific proteins, if they exist, should be helpful for genetic studies, breeding, taxonomy and evolutionary relationships in peanut.

\section{Results \\ Analysis of gel electrophoresis}

Total protein extracts from six runner and six Spanishbunch peanut cultivars and lines were separated by onedimensional SDS-PAGE, and the protein profiles revealed few major difference among all tested peanut genotypes (Fig. 1). Proteins were resolved as four groups (conarachin, acidic arachin, basic arachin, and smaller than $20 \mathrm{kDa}$ ). All but one peanut genotype had three strong bands in the range of 35 to $45 \mathrm{kDa}$, which corresponds to acidic arachins. Runner peanut A13 did not have this $35 \mathrm{kDa}$ polypeptide, a subunit of Ara h3 present in other genotypes. This $35-\mathrm{kDa}$ protein peptide was reported as a $36-\mathrm{kDa}$ protein associated with blanchabil- ity in peanut [12]. A polymorphic protein band with a molecular weight of about $26 \mathrm{kDa}$ were present in all six runner type genotypes and three Spanish derivatives GTYY7, GT-YY79, and GT-YY20, which all have a runner type peanut, Induhuanpi, in their pedigrees (Fig. 1).

We used two-dimensional electrophoresis (2-D PAGE) to achieve a better protein profile of each genotype (Fig. 2 and Fig. 3). Total protein from 12 peanut cultivars or breeding lines was subjected to 2-D PAGE, resulting in about 150 spots found in all cultivars. These protein peptide spots covered a range of isoelectric points $(\mathrm{pIs})(\mathrm{pH}$ $3-10)$ and molecular masses $(10-66 \mathrm{kDa})$. Many components that were recorded on SDS-PAGE gel as a single band (Fig. 1) were resolved into several distinct spots with different pI values by 2-D PAGE gels (Fig. 2 and Fig. 3). The conarachin group (Ara h1) with about $65 \mathrm{kDa}$ molecular weight by SDS-PAGE was separated into many spots with different pIs. Interestingly, the acidic arachin group with three clear bands ranging from $35-45 \mathrm{kDa}$ for all genotypes but A13 (Fig. 1) was resolved into two bands by SDS-PAGE. There was additional polymorphism on 2-D PAGE showing an additional spot in Spanish type peanut as indicated by a arrow head (Fig. 2), which confirmed the report by Bianchi-Hall et al. [9]. The $35 \mathrm{kDa}$ and $26 \mathrm{kDa}$ protein bands, revealed on SDS-PAGE, were confirmed on 2-D PAGE. The basic arachin group with one heavy band on SDS-PAGE at about $22 \mathrm{kDa}$ was separated into several spots or subunits on the 2-D PAGE with distinct isoelectric points and slight differences in molecular weights (Fig. 2 and Fig. 3). These patterns revealed polymorphisms between runner type and Spanish type genotypes. There were four distinct protein spots labelled as spots 14. Spot 1 (ca. $22.5 \mathrm{kDa}, \mathrm{pI} 3.9$ ) and spot 2 (ca. $23.5 \mathrm{kDa}$, pI 5.7) were observed in all Spanish-bunch genotypes, but were not found in those of runner types. In contrast, spot 3 (ca. $23 \mathrm{kDa}, \mathrm{p} I$ 6.6) and spot 4 (ca. $22 \mathrm{kDa}, \mathrm{p} I$ 6.8) were present in all runner genotypes but spot 3 was not in Spanish-bunch type genotypes; spot 4 was present in these accessions with lower concentration. The polymorphic patterns revealed on 2-D PAGE could be used to differentiate subspecies fastigiata (Spanish type) (Fig. 2) and subspecies hypogaea (runner type) (Fig. 3).

\section{Polypeptide sequence analysis}

Protein peptide sequence analysis was conducted. The four polymorphic protein spots 1-4 were excised from the 2-D gels and PVDF membranes for peptide sequencing. For internal sequencing, two to three peptides were randomly picked and sequenced from each spot after in-gel trypsin digestion. The internal and N-terminal peptide sequences obtained for each spot and their homology identified through database searches are summarized in Table 2 and Fig. 4. All peptide fragments had significant sequence homology to known peanut allergens, Ara h3, 


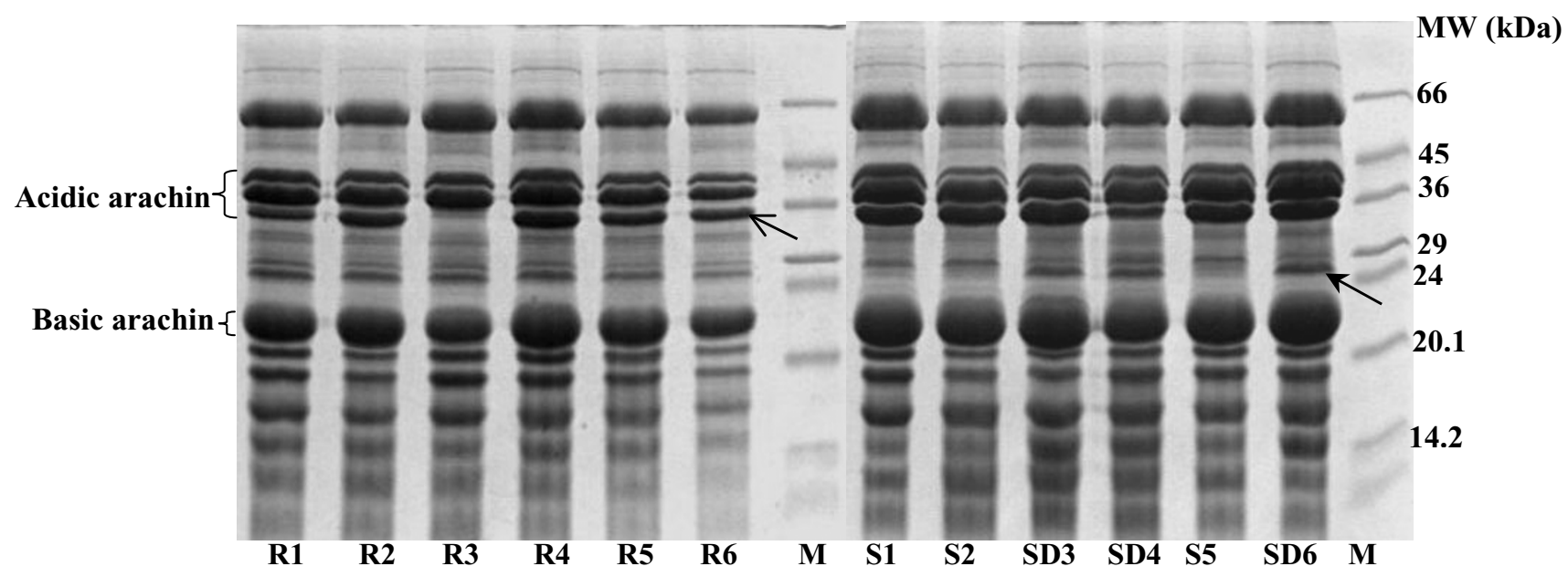

\section{Figure I}

SDS-PAGE peanut seed total protein profiles. One-dimensional SDS-PAGE of peanut seed protein of runner (R) and Spanish (S) or Spanish derivatives (SD): RI = AI04, R2 = GK 7, R3 = AI3, R4 = Tifrunner, R5 = AI00, R6 = Georgia Green; SI = ICGV 95435, S2 = MXHY, SD3 = GT-YY7, SD4 = GT-YY79, S5 = ZQ 48, SD6 = GT-YY20; M = molecular weight standards. The arrow $(\leftarrow)$ indicates the protein band with a molecular weight of $35 \mathrm{kDa}$ and the arrow $(\leftarrow)$ indicates the $26 \mathrm{kDa}$ protein band.

Ara h4, and iso-Ara h3 [13] (Fig. 4). Interestingly, all amino acid sequences of these 4 spots in Fig. 2 and Fig. 3 are present in different regions of peanut allergen proteins as aligned with the published peanut allergen sequences (Fig. 4).

Peptide sequence of spot 1 was unique, and present only in Spanish-type peanuts. Two peptides sequenced after ingel trypsin digestion were the same, while one fragment gave 100\% (FYLAGNQEQEFLR) identity and another fragment gave $88 \%$ ( 14 out of 16 amino acids) identity with iso-Ara h3. The N-terminal sequence (VGQDDPSQQQ) of spot 1 was $100 \%$ identical with iso-Ara h3, whereas Ara h3 and Ara h4 have two amino acids missing in this region (Fig. 4). N-terminal sequencing for spot 2 and spot 3 resulted in the sequences containing VTFRQGG, identical with the sequence for iso-Ara h3 [13]. The N-terminal sequence of spot 4 was GIEETICSASVK, 100\% identical with iso-Ara $\mathrm{h} 3$ and one amino acid (S/T) different from Ara h3 and Ara h4, supporting that spot 4 is the C-terminal part of this protein which always starts with GIEETIC [13].

\section{Discussion}

The initial intention of this study was to profile the storage proteins using improved protein extraction method and to identify protein markers that could be used to sep- arate subspecies of peanut, such as hypogaea and fastigiata, in order to select diverse breeding lines for mapping population construction. Based on the preliminary protein profiles [14], we selected Tifrunner and GT-YY20 for development of recombinant inbred lines (RILs) for genetic mapping. On 2-D PAGE gels, several proteins, labelled as spots 1-4 with similar molecular mass and different pIs, were sequenced. The peptide sequences obtained from these spots were all aligned to peanut allergens, such as iso-Ara h3 (AAT39430), indicating that this single gene encoded protein may be processed differently in different peanut subspecies. The partial cDNA sequence (accession number AY618460) was deposited in GenBank by Kang and Gallo-Meagher [15] in 2004. A full-length cDNA sequence identified in our EST sequencing project has been submitted to GenBank (DQ855115). The internal and N-terminal sequences of peptide spot 1 suggest that the apparent rearrangement of the amino acid sequence has occurred (Fig. 4).

In peanut the majority of seed storage protein (about $87 \%$ ) is globulin consisting of two major fractions, arachin and conarachin [16]. The arachin subunits consist of the acidic polypeptides and the basic polypeptides [17]. The uniformity of the one-dimensional SDS-PAGE protein profiles within the runner type and Spanish type cultivars and breeding lines is in agreement with the studies 

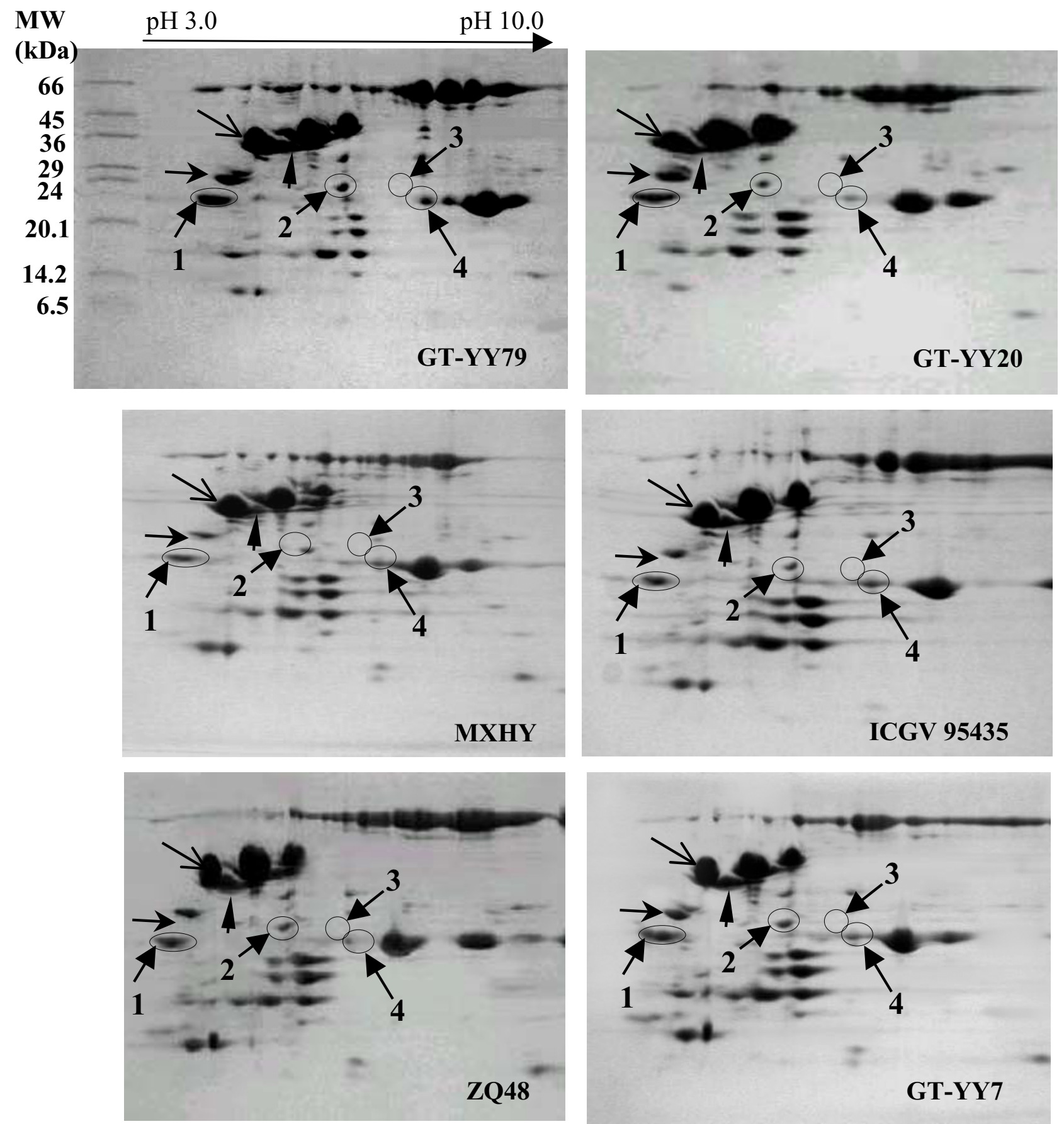

\section{Figure 2}

2-D SDS-PAGE peanut seed total protein profiles. Two-dimensional SDS-PAGE of peanut seed total protein profiles of 6 cultivated peanut genotypes, Spanish market type. Gels are oriented with the acid end of the isoelectric focusing separating to left and the basic end to the right. The arrow $(\leftarrow)$ indicates the protein band with a molecular weight of $35 \mathrm{kDa}$ and the arrow $(\leftarrow)$ indicates the $27 \mathrm{kDa}$ protein band (Fig. I). The arrow head $(-)$ indicates the fourth band as reported for Spanish cultivars [9]. The numbered arrows ( $\rightarrow$ ) pointing to cycled spots indicate the polymorphic polypeptide spots, which were sequenced (Table 2). 

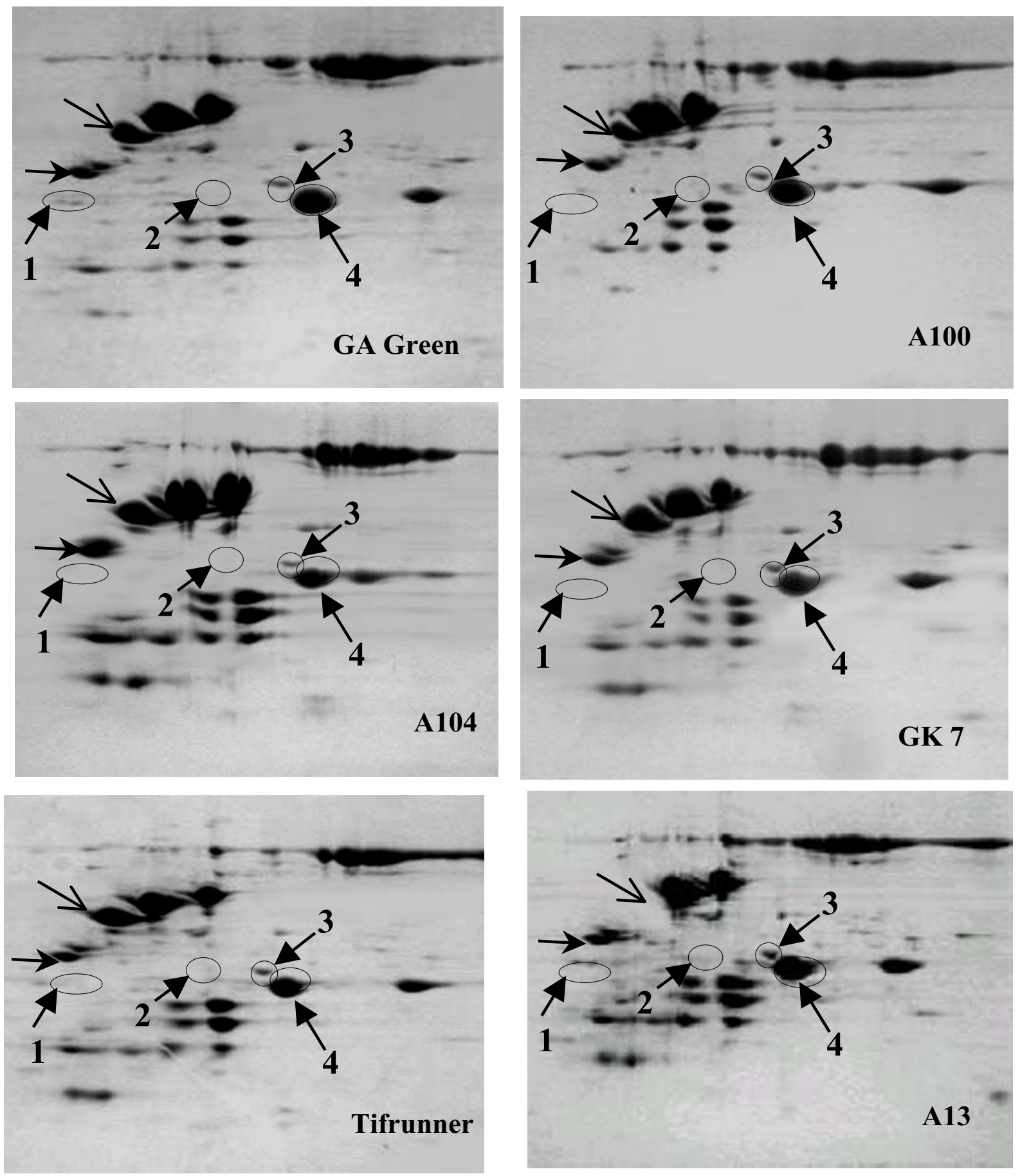

\section{Figure 3}

2-D SDS-PAGE peanut seed total protein profiles. Two-dimensional SDS-PAGE of peanut seed total protein profiles of 6 cultivated peanut genotypes, runner market type. Gels are oriented with the acid end of the isoelectric focusing separating to left and the basic end to the right (Fig. 2). The arrow $(K)$ indicates the protein band with a molecular weight of $35 \mathrm{kDa}$ and the arrow $(\leftarrow)$ indicates the $27 \mathrm{kDa}$ protein band (Fig. I). The numbered arrows $(\rightarrow$ ) pointing to cycled spots indicate the polymorphic polypeptide spots, which were sequenced (Table 2). 
Table I: List of cultivated peanut used in this study

\begin{tabular}{|c|c|c|c|}
\hline Cultivars & Subspecies & Market type & Origin \\
\hline GT-YY20 & fastigiata & Spanish & China \\
\hline GT-YY79 & fastigiata & Spanish & China \\
\hline GT-YY7 & fastigiata & Spanish & China \\
\hline ZQ48 & fastigiata & Spanish & China \\
\hline MXHY & fastigiata & Spanish & China \\
\hline ICGV 95435 & fastigiata & Spanish & India \\
\hline Georgia Green [25] & fastigiata & Runner & USA \\
\hline A $100^{\circ}$ & fastigiata & runner & USA \\
\hline GK7 & fastigiata & runner & USA \\
\hline Tifrunner & fastigiata & runner & USA \\
\hline Al04 & fastigiata & runner & USA \\
\hline $\mathrm{A} 13$ & fastigiata & runner & USA \\
\hline
\end{tabular}

[7-9], indicating that very low variation in protein profiles was detected in cultivated peanut using SDS-PAGE gel electrophoresis.

Generally, SDS-PAGE is not a sufficiently-powerful technique to distinguish a specific cultivar. Therefore, we adopted the widely used protocol developed by Damerval et al. [18] and introduced some modifications including a preliminary de-fatting step of peanut seeds for 2-D PAGE separation. We were able to generate 2-D electrophoresis gel separations with superior resolution and recovery from peanut seeds. Bianchi-Hall et al. [9] reported that the polypeptides of acidic arachin using SDS-PAGE distinguish Spanish from other market type cultivars. In this study, we did not identify the four bands in the range of acidic arachin by SDS-PAGE (Fig. 1), but we could detect the fourth spot of protein on 2-D PAGE for Spanish type genotypes (Fig. 2). We also detected a $26 \mathrm{kDa}$ polypeptide by SDS-PAGE; this polypeptide could be used to differentiate Spanish and runner.

\section{Conclusion}

This study demonstrated that two-dimensional electrophoresis (2-D PAGE) achieved a better resolution of protein profiles of peanut seeds, revealing polymorphisms between runner and Spanish genotypes. The basic arachin group, having one heavy band on SDS-PAGE gels at about $22 \mathrm{kDa}$, was resolved into several spots or subunits on the
2-D PAGE with distinct isoelectric points and slight differences in molecular weights. These proteins are isoforms (iso-Ara h3) of each other and the iso-allergens may be modified by post-translational cleavage. These results suggest that there may be an association between these polymorphic storage protein isoforms and peanut subspecies fastigiata (Spanish type) and hypogaea (runner type). Future studies could be designed to test the allergenic reactions of these peanut genotypes with different protein profiles and association with the resistance to aflatoxin contamination [19].

\section{Methods}

\section{Plant materials}

Twelve peanut genotypes were used in this study. There were six runner-type peanut genotypes: Georgia Green, A100, A104, GK7, A13 and Tifrunner, and six Spanishbunch type peanut genotypes: ICGV 95435 (International Crops Research Institute for the Semi-Arid Tropics, Patancheru, India), MXHY and ZQ48 (Chinese landraces), and GT-YY20, GT-YY7 and GT-YY79 (Spanish derivatives with runner type peanut in their pedigrees, obtained from Crops Research Institute, Guangdong Academy of Agricultural Sciences, China). To avoid the effects of different locations, all genotypes were grown in Tifton, GA in 2003. Seeds were harvested at full maturity per normal production practices. After harvest, seeds were air-dried at $40{ }^{\circ} \mathrm{C}$ and stored at $4{ }^{\circ} \mathrm{C}$ before use.

Table 2: Internal peptide and $\mathrm{N}$-terminal sequences of some protein spots of cultivated peanut

\begin{tabular}{cll}
\hline Spot ${ }^{\prime}$ & Internal peptide sequence & N-terminal peptide sequence \\
\hline 1 & FYLAGNQEQEFLR NPDLEEFQCAGVALSR & VGQDDPSQQQ \\
2 & FYLAGNQEQEFLR NPDLEEFQCAGVALSR & VTFRQGGEENEC \\
3 & QGGEENECQFQR FHLAGNQEQEFLR IESEGGYIETWNPNNQEFECAGVALSR & VTFRQGGEENEC \\
4 & AQSENYEYIAFK VYDEELQEGHVLVPQNFAVAAK & GIEETICSASVK \\
\hline
\end{tabular}

'Spot numbers are corresponding to the spot numbers in Fig. 2. 


\begin{tabular}{|c|c|c|c|c|c|c|c|}
\hline Ara & 1 & MAKLLELSFC & FCFLVLGASS & ISFRQQPEEN & ACQFQRLNAQ & RPDNRIESEG & GYIETWNPNN \\
\hline Ara h3 & 1 & --------- & --------- & - - -RQQPEEN & ACQFQRLNAQ & RPDNRIESEG & GYIETWN_N \\
\hline Iso-Ara h3 & 1 & MAKLLALSLC & FCVLVLGASS & VTFRQGGEEN & ECQFERLNAQ & RPDNRIESEG & GYIETWNPNN \\
\hline Spot $1 \& 2 \quad$ (I) & & -------- & -------- & -------- & -------- & -------- & $-----N P D L$ \\
\hline Spot 3 (I) & & -------- & -------- & -- - -QGGEEN & ECQFQR - - - & ---- - IESEG & GYIETWNPNN \\
\hline Spot $2 \& 3 \quad(N)$ & & -------- & -------- & VTFRQGGEEN & & & \\
\hline Ara h4 & 61 & QEFECAGVAL & SRLVLRRNAL & RRPFYSNAPQ & EIFIQQGRGY & FGLIFPGCPS & TYEEPAQQGR \\
\hline Ara h3 & 61 & QEFECAGVAL & SRLVLRRNAL & RRPFYSNAPQ & EIFIQQQGRGY & FGLIFPGCPR & HYEEPHTQGR \\
\hline Iso-Ara h3 & 61 & QEFQCAGVAL & SRTVLRRNAL & RRPFYSNAPL & EIYVQQGSGY & FGLIFPGCPS & TYEEPAQEGR \\
\hline Spot $1 \& 2$ (I) & & EEFQCAGVAL & $\mathrm{SR}$ & & & & \\
\hline Spot 3 (I) & & QEFECAGVAL & SR & & & & \\
\hline Ara h4 & 21 & YQSQRPPRR & LQE - EDQSQ & QQQDSHQKVH & RFNEGDLIAV & PTGVAFWLYN & DHDTDVVAVS \\
\hline Ara h3 & 121 & RSQSQRPPRR & LQG - - EDQSQ & QQRDSHQKVH & RFDEGDLIAV & PTGVAFWLYN & DHDTDVVAVS \\
\hline Iso-Ara h3 & 121 & RYQSQKQRSRR & FQVGQDDPSQ & QQQDDSHQKVH & RFDEGDLIAV & PTGVAFWMYN & DEDTDVVTVT \\
\hline Spot 1 (N) & & --------- & - -VGQDDPSQ & & & & \\
\hline Ara h4 & 181 & LTDTNNNDNQ & LDQFPRRFNL & AGNHEQEFLR & YQQQSRQSRR & RSLPYSPYSP & HSRPRREERE \\
\hline ra h3 & 181 & LTDTNNNDNQ & LDQFFPRFNL & AGNTEQEFLR & YQQQSRQSRR & RSLPYSPYSP & QSQPRQEERE \\
\hline Iso-Ara h3 & 181 & LSDTSS IHNQ & LDQFPRRFYL & AGNQEQEFLR & YQQQQG - - - - & -------- & -SRP- -HYRQ \\
\hline Spot $1 \& 2$ (I) & & --------- & $------F Y L$ & AGNQEQEFLR & & & \\
\hline Spot 3 (I) & & --------- & ------ FHL & AGNQEQEFLR & & & \\
\hline ra h4 & 241 & FRPRGQHSRR & ERAGQEEEDE & GGNIFSGFTP & EFLEQAFQVD & DRQIVQNLWG & ENESEEEGAI \\
\hline ra h3 & 241 & FSPRGQHSRR & ERAGQEEENE & GGNI_SG_TP & E_EQAFQVD & DRQIVQNLRG & ETESEEEGAI \\
\hline Iso-Ara h3 & 241 & ISPR---- - - & -VRGDEQENE & GSNIFSGFAQ & $\overline{E F L Q H A F Q V D}$ & -RQTVENLRG & ENEREEQGAI \\
\hline ra h4 & 01 & VTVRGGLRIL & SPDGTRGADE & E-----EEYD & EDQYEYHEQD & GRRGRGSRGG & GNGIEETICT \\
\hline Ara h3 & 301 & VTVRGG_RII & S_DRKRRADE & E-----EEYD & $\mathrm{EDEY}$ & RRGRGSRGR & GNGIEETICT \\
\hline Iso-Ara h3 & 301 & VTVKGGLRIL & SPDEEDESSR & SPPSRREEFD & EDRSRP-QQR & GKYDENRRGY & KNGIEETICS \\
\hline Spot 4 (N) & & ---------- & --------- & --------- & --------- & --------- & - -GIEETICS \\
\hline Ara h4 & 61 & ACVKKNIGGN & RSPHIYDPQR & WFTQNCHDLN & LLILRWLGLS & AEYGNLYRNA & LFVPHYNTNA \\
\hline Ara h3 & 361 & ASAKKNIGRN & RSPDIYNPQA & GSLKTANDLN & LLILRWLGPS & AEYGNLYRNA & LFVAHYNTNA \\
\hline Iso-Ara h3 & 361 & ASVKKNLGRS & SNPDIYNPQA & GSLRSVNELD & LPILGWLGLS & AQHGTIYRNA & MFVPHYTLNA \\
\hline Spot 4 (N) & & & & & & & \\
\hline ra h4 & 421 & HSI IYALRGR & AHVQVVDSNG & NRVYDEELQE & GHVLVVPQNF & AVAGKSQSEN & FEYVAFKTDS \\
\hline Ara h3 & 421 & HSI IYRLRGR & AHVQVVDSNG & NRVYDEELQE & GHVLVVPQNF & AVAGKSQSEN & FEYVAFKTDS \\
\hline Iso-Ara h3 & 421 & HTIVVALNGR & AHVQVVDSNG & NRVYDEELQE & GHVLVVPQNF & AVAAKAQSEN & YEYLAFKTDS \\
\hline Spot 4 (I) & & -------- & -------- & - -VYDEELQE & GHVLVVPQNF & AVAAKAQSEN & YEYLAFK - - - \\
\hline ra & 481 & RPSIANFAGE & NSFIDNLPEE & VVANSYGLPR & EQARQLKNNN & PFKFFVPPF- & QQSPRAVA \\
\hline Ara h3 & 481 & RPSIANLAGE & NSVIDNLPEE & VVANSYGLQR & EQARQLKNNN & PFKFFVPPS - & QQSPRAVA \\
\hline Iso-Ar & 481 & RPSIANLAGE & NSI IDNLPEE & VVANSYRLPR & EQARQLKNNN & PFKFFVPPFD & HQSMREVA \\
\hline
\end{tabular}

\section{Figure 4}

Amino acid sequences alignment. Amino acid sequences alignment of peptide sequences $(N=N$-terminal sequences; $I=$ internal sequences by using in-gel trypsin digestion and sequencing), in bold-faced, of spots I-4 with the published peanut allergen sequences of Ara h4 (AAD47382), Ara h3 (AAC63045), and iso-Ara h3 (ABII 7I 54) (26). Sequences obtained by N-terminal sequencing are shaded in black. The different amino acid residues are colored in red. The amino acid sequences of Ara h3 lgEbinding epitopes [24] are shaded in gray and the critical amino acids to lgE binding are colored in green and underlined.

\section{Total protein extraction}

The total protein extraction was modified from TCA/Acetone protein extraction protocol [18] with the first step of de-fatting using hexane. Dry peanut kernels (20 g) of each genotype were frozen in liquid nitrogen and ground to powder in a mill and defatted with hexane $(10 \mathrm{ml} / \mathrm{g}$ dry weight) at $-20^{\circ} \mathrm{C}$ overnight. The defatted samples were collected by centrifugation $(15,000 \times \mathrm{g}$ for $10 \mathrm{~min}$ at $4{ }^{\circ} \mathrm{C}$ ), air-dried, and ground to a fine powder in a prechilled mortar and pestle in liquid nitrogen. Protein 
extraction and precipitation were performed in $10 \%(\mathrm{w} / \mathrm{v})$ trichloroacetic acid in cold acetone with $0.07 \%(\mathrm{v} / \mathrm{v}) \beta$ mercaptoethanol at $-20^{\circ} \mathrm{C}$ for $2 \mathrm{~h}$, followed by centrifugation at $10,000 \times \mathrm{g}$ for $10 \mathrm{~min}$ at $4{ }^{\circ} \mathrm{C}$. The pellets were washed twice with cold acetone containing $0.07 \% \beta$-mercaptoethanol, followed by washing twice with cold $80 \%$ acetone and then centrifuged at $10,000 \times \mathrm{g}$ for $10 \mathrm{~min}$ at $4^{\circ} \mathrm{C}$. The pellets were air dried and stored at $4{ }^{\circ} \mathrm{C}$ overnight. The total proteins were dissolved in lysis buffer (10 $\mu \mathrm{l} / \mathrm{mg}$ ) containing $9.5 \mathrm{M}$ urea, 4\% Igepal CA-360 (Sigma, St. Louis, MO), 2.5\% ampholytes $(0.5 \% \mathrm{pH} 3.0-10,0.5 \%$ $\mathrm{pH} 4-6$, and $1.5 \% \mathrm{pH} \mathrm{6-8)} \mathrm{(Sigma),} \mathrm{5 \%} \beta$-mercaptoethanol, and kept at $35^{\circ} \mathrm{C}$ for $30 \mathrm{~min}$. After centrifugation $\left(15,000 \times \mathrm{g}, 20 \mathrm{~min}, 25^{\circ} \mathrm{C}\right)$, the supernatant was collected for loading in first-dimension gel electrophoresis, or alternatively, for storing at $-20^{\circ} \mathrm{C}$ until use. The supernatant protein concentration was determined using the Bradford [20] assay. The experiment was conducted twice, and each genotype was run at least three times.

\section{SDS-PAGE and two-dimensional PAGE electrophoresis}

Total protein samples from these twelve peanut genotypes were first profiled using SDS-PAGE (15\% separating gel with $4 \%$ stacking gel) according to the method of Laemmli [21] with the Mini-PROTEIN ${ }^{\circledR} I$ D Dual Slab Cell System (BIO-RAD, Hercules, CA) [22]. Total proteins (100 $\mu \mathrm{g})$ from each sample were loaded onto SDS-PAGE gels. Low-range protein markers (Sigma) were used as molecular mass standard. The gels were electrophoresed $(120 \mathrm{~V}$, $1.5 \mathrm{~h}$ ), stained with $0.125 \%$ Coomassie blue R-250 in $40 \%$ methanol and $10 \%$ acetic acid. For 2-D PAGE, total seed proteins $(1 \mathrm{mg})$ were loaded into tube gels $(8 \mathrm{M}$ urea, $4 \%$ acrylamide, $2 \%$ Igepal CA-630, 0.5\% ampholyte $\mathrm{pH}$ 3.0-10, 0.5\% ampholyte $\mathrm{pH} 4-6,1.5 \%$ ampholyte $\mathrm{pH} 6-$ $8,0.01 \%$ ammonium persulfate, and $0.1 \%$ TEMED), and overlaid with $20 \mu \mathrm{l}$ sample overlay buffer (4 M urea, $0.25 \%$ ampholyte $\mathrm{pH} 3.0-10,0.25 \%$ ampholyte $\mathrm{pH} 4-6$, $0.75 \%$ ampholyte pH $6-8,2.5 \% \beta$-mercaptoethanol, $1 \%$ Igepal CA-360, and $0.05 \%$ Bromophenol blue). Isoelectric focusing (IEF) was conducted by using Mini-Protean ${ }^{\circledast}$ 2-D Electrophoresis Cell (BIO-RAD). The upper and lower chamber buffers were $100 \mathrm{mM} \mathrm{NaOH}$ and $10 \mathrm{mM} \mathrm{H}_{3} \mathrm{PO}_{4}$ respectively. IEF conditions were $200 \mathrm{~V}$ for $15 \mathrm{~min}, 300 \mathrm{~V}$ for $15 \mathrm{~min}, 400 \mathrm{~V}$ for $30 \mathrm{~min}$, and $750 \mathrm{~V}$ for $6 \mathrm{~h}$. The focused tube gels were equilibrated immediately for 30 min in $10 \mathrm{ml}$ SDS equilibration buffer $(60 \mathrm{mM}$ Tris- $\mathrm{HCl}$, pH6.8, 2\% SDS, $10 \%$ glycerol, and $0.05 \%$ Bromophenol blue), or kept at $-20^{\circ} \mathrm{C}$ until use. After equilibration, the tube gels were embedded in a $1 \%$ agarose solution at the top of the 2-D gel. The second dimension was run on 15\% polyacrylamide-SDS gels in a Mini-Protean ${ }^{\circledR} 3$ Cell (BIORAD), $120 \mathrm{~V}$ for $90 \mathrm{~min}$. The gels were stained with Coomassie Brilliant Blue R250 and all gels were scanned and the spot intensities were analyzed using the software Image Master-2D (BIO-RAD). The interesting spots of seed protein among the genotypes were identified by gelto-gel comparison. For molecular weight determination, low molecular weight standard (Sigma) was used.

\section{Peptide sequencing}

Protein peptides were excised from the 2-D gels and PVDF membranes for peptide sequencing using electrospray ionization tandem mass spectrometry (ESI-MS/MS) to obtain internal peptide sequences and using the conventional Edman degradation method to obtain N-terminal sequences. Protein spots from the gels were excised with combined total protein amount up to $10 \mathrm{pg}$, and were subjected to in-gel digestion and analysis by ESI-MS/MS to obtain peptide sequence information at the Protein Chemistry Core Facility, Baylor College of Medicine (Houston, TX). When peptide sequences could not be obtained unambiguously by using ESI-MS/MS, Edman degradation was performed using an Applied Biosystems Procise cLC sequencer to obtain sequence information for protein identification.

\section{Electrobloting and $\mathbf{N}$-terminal sequence}

To prevent $\mathrm{N}$-terminal blockage during second-dimension gel electrophoresis, gels were poured at least $24 \mathrm{hr}$ prior to running and $0.1 \mathrm{mM}$ thiodiglycolate was added as a scavenger in the upper running buffer. 2-D gels were equilibrated for $30 \mathrm{~min}$ in $25 \mathrm{mM}$ Tris, $192 \mathrm{mM}$ glycine, $10 \% \mathrm{MeOH}$ ( $\mathrm{pH} 8.3$ ), and then electroblotted to Immobilon-p PVDF-membrane (Millipore, Bedford, MA, USA) at $300 \mathrm{~mA}$ for $4 \mathrm{hr}$ in a Mini Trans-Blot ${ }^{\circledast}$ Electrophoretic Transfer Cell (BIO-RAD). The membrane was subsequently equilibrated for $5 \mathrm{~min}$ in deionized water and proteins stained with $0.05 \%$ Coomassie Blue in $1 \%$ acetic acid and 50\% methanol for a few min, destained in 50\% methanol until background was pale blue. The membrane was rinsed for 5-10 min in deionized water and air-dried. Spots were excised and used for $\mathrm{N}$-terminal amino acid microsequencing at Baylor Medical School (Houston, TX).

\section{Database sequence homology analysis}

Internal and $\mathrm{N}$-terminal peptide sequence homology identification was performed using basic local alignment search tool (BLAST) [23] against known or translated open reading frames of expressed sequence tags (ESTs) in the databases at the National Center for Biotechnology Information (NCBI) and SWISS-Prot.

\section{Authors' contributions}

XQL performed the experiments and wrote the first draft of the manuscript. ML performed the sequence search and $\mathrm{CCH}$ provided plant materials. BZG conceived the research and revised the manuscript. All authors read and approved the final manuscript. 


\section{Acknowledgements}

We thank Ernest Harris and Kippy Lewis for technical assistance in the field and the laboratory. This research was supported partially by funds provided by USDA Agricultural Research Service and Peanut Foundation, and by funds provided by Scientific Cooperation Research Program of U. S.

Department of Agriculture-Foreign Agricultural Service between U.S. and China. Mention of trade names or commercial products in this publication is solely for the purpose of providing specific information and does not imply recommendation or endorsement by the U.S. Department of Agriculture.

\section{References}

I. Krapovickas SA, Rigoni VA: Taxonomia del genero Arachis (Leguminosae). Bonplandia 1994, 8: I-I86.

2. Stalker HT, Philips TD, Murphy JP, Jones TM: Variation of isozyme patterns among Arachis species. Theor Appl Genet 1994, 87:746-755.

3. Kochert G, Halwart T, Branch WD, Simpson CE: RFLP variability in peanut (Arachis hypogaea L.) cultivars and wild species. Theor Appl Genet 199I, 8I:565-570.

4. Halward TM, Stalker TH, LaRue E, Kochert G: Genetic variation detectable with molecular markers among unadapted germplasm resources of cultivated peanut and related wild species. Genome 1991, 34:1013-1020.

5. He GC, Prakash S: Identification of polymorphic DNA markers in cultivated peanut (Arachis hypogaea L.). Euphytica 1997, 97:|43-149.

6. He G, Meng R, Gao H, Guo B, Gao G, Newman M, Pittman R, Prakash $C S$ : Simple sequence repeat markers for botanical varieties of cultivated peanut (Arachis hypogaea L.). Euphytica 2005, |42:131-| 36.

7. Singh AK, Sivaramakrishnan S, Mengesha MH, Ramaiah CD: Polygenetic relation in section Arachis based on seed protein profile. Theor Appl Genet 199I, 82:593-597.

8. Singh AK, Santosh G, Jambunathan R: Phylogenetic relationship in the genus Arachis based on seed protein profiles. Euphytica 1994, 74:219-225.

9. Bianchi-Hall CM, Keys RD, Stalker TH: Use of seed protein profiles to characterize peanut cultivars. Peanut Sci 1994, 2I:I52-159.

10. Thiellemmet H, Bahrnman N, Damerval C, Plomion C, Rossignol M, Santony V, Vienne D, De Zivy M: Proteomics for genetic and physiological studies in plant. Electrophoresis 1999, 20:2013-2026.

II. Park OK: Proteomic studies in plants. J Biochem Mol Biol 2004, 37:133-138.

12. Shokraii EH, Esen A, Mozingo RW: Relation of a 36,000-dalton arachin subunit to blanch ability in peanut (Arachis hypogaea L.). J Agric Food Chem 1985, 33: I I I4-I II6.

13. Boldt A, Fortunato D, Conti A, Petersen A, Ballmer-Weber B, Lepp $U$, Reese G, Becker W-M: Analysis of the composition of an immunoglobulin $E$ reactive high molecular weight protein complex of peanut extract containing Ara $h \mathrm{I}$ and Ara $h$ 3/4. Proteomics 2005, 5:675-686.

14. Guo BZ, Liang XQ, Maleki SJ, Chung SY, Holbrook CC, Ozias-Akins $P$ : Characterization of five seed-proteins missing in one peanut genotype and the allergic nature of these proteins. Proceeding of the thirty-sixth annual meeting of the American Peanut Research and Education Society (APRES). San Antonio, Texas 2004:28. July I3-16, 2004

15. Kang I-H, Gallo-Meagher M: Cloning and characterization of a novel ara h 3, a major peanut (Arachis hypogaea L.) allergen gene. GenBank 2004 [http://www.ncbi.nlm.nih.gov.]. National Center for Biotechnology Information Accession Number AY6I 8460

16. Basha SM, Pancholy SK: Polypeptide composition of arachin and non-arachin proteins from early bunch peanut (Arachis hypogaea L.) seed. Peanut Sci 1981, 8:82-88.

17. Krisha TG, Mitra R: Arachin polymorphism in groundnut (Arachis hypogaea L.). Phytochemistry 1987, 26:897-902.

18. Damerval C, de Vienne D, Zivy M, Thiellement H: The technical improvements in two-dimensional electrophoresis increase the level of genetic variation detected in wheat-seedling proteins. Electrophoresis 1986, 7:52-54.
19. Liang XQ, Guo BZ, Holbrook CC: Identification of peanut seedstorage proteins associated with resistance against Aspergillus flavus infection and aflatoxin production. Proceeding of the thirty-sixth annual meeting of the American Peanut Research and Education Society (APRES). San Antonio, Texas 2004:74. July 13-16, 2004

20. Bradford $M: A$ rapid and sensitive method for the quantitation of microgram quantities of protein utilizing the principal of protein-dye binding. Anal Biochem 1976, 72:248-254.

21. Laemmli UK: Cleavage of structural proteins during the assembly of the head of bacteriophage T4. Nature 1970, 227:239-25I.

22. Guo BZ, Brown RL, Lax AR, Cleveland TE, Russin JS, Widstrom NW: Protein profiles and antifungal activities of kernel extracts from corn genotypes resistant and susceptible to Aspergillus flavus. J Food Prot 1998, 61:98-102.

23. Altschul SF, Gish W, Miller W, Myers EW, Lipman DJ: Basic local alignment search tool. I Mol Biol 1990, 2 I 5:403-4I0.

24. Rabjohn P, Helm EM, Stanley JS, West CM, Sampson HA, Burks AW, Bannon GA: Molecular cloning and epitope analysis of the peanut allergen Ara h3. J Clin Invest 1999, 103:535-542.

25. Branch WD: Registration of 'Georgia Green' peanut. Crop Sci 1996, 36:806.

26. Guo B, Chen H, Dang $P$, Chen $X$, Liang $X$, Holbrook C: Identification of a new potential peanut seed allergen iso-Ara $h 3$. GenBank 2006 [http://www.ncbi.nlm.nih.gov.]. National Center for Biotechnology Information Accession Number DQ855I I5
Publish with Bio Med Central and every scientist can read your work free of charge

"BioMed Central will be the most significant development for disseminating the results of biomedical research in our lifetime. "

Sir Paul Nurse, Cancer Research UK

Your research papers will be:

- available free of charge to the entire biomedical community

- peer reviewed and published immediately upon acceptance

- cited in PubMed and archived on PubMed Central

- yours - you keep the copyright

Submit your manuscript here:

http://www.biomedcentral.com/info/publishing_adv.asp
BioMedcentral 